\title{
REPOSISI PERAN WAQAF DALAM PEMBERDAYAAN EKONOMI ISLAM DALAM KAJIAN UNDANG-UNDANG NOMOR 41 TAHUN 2004 TENTANG WAQAF
}

\author{
REPOSISI ROLE OF WAKAF IN ISLAMIC ECONOMIC \\ EMPOWERMENT IN THE STUDY OF THE LAW NUMBER 41 \\ YEAR 2004 ABOUT WAQAF
}

Muhammad Junaidi

Magister Hukum Universitas Semarang

Email : institut.junaidi@gmail.com

\author{
Abdullah Kelib \\ Magister Hukum Universitas Semarang \\ Email : abdullahkelib@ums.ac.id \\ Diah Sulistiyani R S \\ Magister Hukum Universitas Semarang \\ Email : diahsrs@ums.ac.id
}

Naskah diterima : 02/04/2018; direvisi : 20/04/2018; disetujui : 27/04/2018

\begin{abstract}
One of the supporting instruments in Islamic law is Waqaf, which is a part of muamalah or Islamic civil law. Wagaf doctrine is not only highlighting the implementation of relationship between men and God, yet highlighting men to men relationship. The discussion concerning wakaf in term of men to men relationship requires further analysis, particularly its effort and role in public empowerment through the perspective of Law number 41 of 2004 concerning wakaf. This research is applying juridical-normative approaching method. Through such approach, this research is directed to analyze existing text, norms and rules to be further examines its validity with higher norms. This research is using secondary data that consist of primary, secondary and tertiary legal substances. Thus, this research is expected to be a firming element of future strategic policies related to waqaf implementation in term of public empowerment. Besides, its analysis result is aimed to enhance the references in the area of Islamic law study, especially related to wagaf empowerment which is taught in university level. The optimization of wakaf empowerment cannot be maximally implemented without support from establish public legal culture and institution structure.
\end{abstract}

Keywords: Reposition, Waqaf, Empowering

\begin{abstract}
Abstrak
Salah satu instrument pendukung dalam hukum Islam yang termasuk bagaian dari muamalah adalah wakaf. Wakaf merupakan bentuk ajaran yang menitiktekankan bukan hanya implementasi hubungan antara tuhan dan manusia akan tetapi juga menekankan terjalinnya hubungan manusia dengan manusia. Persoalan wakaf dalam tinjauan hubungan antara manusia inilah yang kemudian perlu dicermati dari sisi upaya dan peran wakaf dalam pemberdayaan ummat yang utamanya dalam perspektif Undang-Undang Nomor 41 tahun 2004 tentang Wakaf. Metode penelitian ini adalah penelitian yuridis normatif. Dalam pendekatannya penelitian diarahkan
\end{abstract}


untuk menganalisis teks dan norma-norma dan kaidah-kaidah yang berkembang untuk kemudian menguji keberlakuannya dengan norma yang ada di atasnya. Sedangkan data yang digunakan dalam hal ini adalah data sekunder yang terdiri dari bahan hukum primer, bahan hukum sekunder dan bahan hukumtersier. Melalui penelitian yang dilakukan diharapkan dapat menjadi instrument penegas kebijakan-kebijakan strategis pada masa yang akan datang terkait bagaimana implementasi wakaf dalam upaya pemberdayaan ekonomi ummat. Disamping itu, hasil kajian yang dilakukan dalam menambah referensi utamanya dalam kajian hukum Islam terkait pemberdayaan wakaf yang diajarkan utamanya diperguruan tinggi. Kebutuhan optimalisasi pemberdayaan wakaf melalui Undang-Undang Nomor 41 tahun 2004 tentang Wakaf tidaklah sebuah wujud wawasan yang strategis untuk diterapakan apabila budaya hukum baik masyarakat maupun struktural kelembagaan wakaf tidak berjalan dengan baik.

\section{Kata kunci : Reposisi, Wakaf dan Pemberdayaan}

\section{PENDAHULUAN}

Di negara hukum, prinsip-prinsip untuk mengakomodasi hak-hak yang dilindungi oleh setiap warga negara menjadi jaminan yang bersifat pasti diberikan dan dilindungi secara konstitusional. Hal tersebut tidak terkecuali hak-hak dalam menjalankan ajaran agama baik yang memiliki makna hubungan antara tuhan dan individu maupun makna hubungan antara individu dengan individu yang lain.

Salah satu perlindungan yang diberikan oleh negara dalam ajaran agama dalam hal ini dapat dicontohkan bentuknya yaitu wakaf. Undang-Undang Republik Indonesia Nomor 41 Tahun 2004 Tentang Wakaf merupakan perwujudan peran negara dalam menjamin itu semua. Dalam konsideran dinyatakan :

a. bahwa lembaga wakaf sebagai pranata keagamaan yang memiliki potensi dan manfaat ekonomi perlu dikelola secara efektif dan efisien untuk kepentingan ibadah dan untuk memajukan kesejahteraan umum; dan

b. bahwa wakaf merupakan perbuatan hukum yang telah lama hidup dan dilaksanakan dalam masyarakat, yang pengaturannya belum lengkap serta masih tersebar dalamberbagai peraturan perundang-undangan.

Prinsip dasar keterlibatan negara dalam menjamin ajaran agama merupakan bentuk lain dari keberpihakan agama terhadap kepentingan yang ada baik mayoritas maupun minoritas. Konsep inilah yang menjadi ciri khas dari gagasan negara hukum sebagaimana Indonesia dituangkan dalam pasal 1 ayat (3) UndangUndang Dasar Negara Republik Indonesia tahun 1945.

Hukum dengan tegas mengatur segala tingkah laku lahiriah dan ingin menciptakan keseimbangan diantara kepentingan warga masyarakat yang berbeda satu dengan yang lain. Di setiap negara, pasti memiliki ciri-ciri hukumnya sendiri-sendiri. Seperti contohnya di Indonesia. Negara Hukum Indonesia memiliki ciri-ciri khas Indonesia. Karena Pancasila harus diangkat sebagai dasar pokok dan sumber hukum, maka negara hukum Indonesia dapat pula dinamakan negara hukum Pancasila. Salah satu ciri pokok dalam negara hukum Pancasila ialah adanya jaminan terhadap freedom of religion atau kebebasan beragama. Tetapi, kebebasan beragama di negara hukum Pancasila selalu dalam konotasi yang positif, artinya tiada tempat bagi ateisme atau propaganda anti agama di bumi Indonesia. ${ }^{1}$

Kebebasan warga negara sangat erat kaitannya dengan "hak asasi" atau human right, terutama dengan hak asasi yang paling fundamental antara lain :

a. Kebebasan untuk bergerak atau berpindah

\footnotetext{
${ }^{1}$ Muhammad Tahir Azhary, Negara Hukum, Prenada Media, Jakarta, 2003, hlm. 93
} 
b. Kebebasan untuk berkumpul atau berorganisasi

c. Kebebasan berbicara secara lisan atau tertulis

d. Kebebasan beragama dan beribadah

e. Kebebasan berkontrak dalam bidang perdata

f. Kebebasan mencapai kesejahteraan dan kebahagiaan. $^{2}$

Prinsip dasar pokok inilah yang dicoba dibangun melalui wakaf. Kebebsan personal warga masyarakat dijamin secara konstitusional berdasarkan ketentuan perundang-undangan yang berlaku. Namun jaminan tersebut meskipun diklasifikasikan hak, akan tetapi tetapi suatau perspektif hak memiliki prinsip kepentingan personal maupun kepentingan negara dalam menjamin kesejahteraan bagi segenap warga masyarakat.

Hal inilah yang diatur secara konstitusional dalam Undang-Undang Republik Indonesia Nomor 41 Tahun 2004 Tentang Wakaf bahwa dengan lahirnya peraturan perundang-undangan dalam penjelasan dinyatakan bahwa :

a. Salah satu langkah strategis untuk meningkatkan kesejahteraan umum, perlu meningkatkan peran wakaf sebagai pranata keagamaan yang tidak hanya bertujuan menyediakan berbagai sarana ibadah dan sosial, tetapi juga memiliki kekuatan ekonomi yang berpotensi,antaralainuntukmemajukan kesejahteraan umum, sehingga perlu dikembangkan pemanfaatannya sesuai dengan prinsip syariah.

b. Praktik wakaf yang terjadi dalam kehidupan masyarakat belum sepenuhnya berjalan tertib dan efisien sehingga dalam berbagai kasus harta benda wakaf tidak terpelihara sebagaimana mestinya, terlantar atau beralih ke tangan pihak ketiga dengan caramelawanhukum.Keadaandemikian

${ }^{2}$ Ahmad Kamil, M. Fauzan, Kaidah-Kaidah Hukum Yurisprudensi, Prenada Media, Jakarta, 2004, hlm. 18 itu, tidak hanya karena kelalaian atau ketidakmampuan Nazhir dalam mengelola dan mengembangkan harta benda wakaf tetapi karena juga sikap masyarakat yang kurang peduli atau belum memahami status harta benda wakaf yang seharusnya dilindungi demi untuk kesejahteraan umum sesuai dengan tujuan, fungsi, dan peruntukan wakaf.

Salah satu kongklusi dalam ketentuan tersebut di atas adalah amanat pemberdayaan wakaf untuk kepentingan ummat. Menurut data yang dihimpun Departemen Agama RI, jumlah tanah wakaf di Indonesia mencapai 2.686.536.656, 68 meter persegi (dua milyar enam ratus delapan puluh enam juta lima ratus tiga puluh enam ribu enam ratus lima puluh enam koma enam puluh delapan meter persegi) atau 268.653,67 hektar (dua ratus enam puluh delapan ribu enam ratus lima puluh tiga koma enam tujuh hektar) yang tersebar di 366.595 lokasi di seluruh Indonesia ${ }^{3}$.

Namun persoalan yang perlu ditegaskan adalah pemberdayaan potensi wakaf sudah semestinya dikaji sejauh mana dapat memberdayakan masyarakat dengan melihat jumlah potensi yang ada tersebut. Oleh karenanya kajian potensi melalui pendekatan penelitian terhadap keberlakuan norma-norma yang ada dalam Undang-Undang Republik Indonesia Nomor 41 Tahun 2004 Tentang Wakaf sudah semestinya dilakukan agar kedepannya potensi wakaf dalam memberdayakan ummat dapat direalisasikan dengan baik.

\section{PEMBAHASAN}

Melalui kelahiran Undang-Undang Nomor 41 tahun 2004 tentang Wakaf yang pada prinsipnya mengatur masalah wakaf. Fungsi negara dalam mengatur atau mengundang-undangkan wakaf bukan

${ }^{3}$ Database dan Potensi Wakaf, diunduh pada situs http://www.bwi.or.id pada 25 Agustus 2017 
Muh. Junaidi, Abdullah Kelib \& Diah Sulistiyani R S|Reposisi Peran Waqaf Dalam Pemberdayaan........

mengintervensi wakaf, akan tetapi lebih pada upaya menjaga ketertiban dalam pelaksanaan wakaf agar berjalan sesuai orientasi yang seharusnya.

Hal ini jelas telah diterangkan dalam bagian penjelasan yang diuraikan sebagai berikut :

Tujuan Negara Kesatuan Republik Indonesia sebagaimana diamanatkan dalam Pembukaan Undang-Undang Dasar Negara Republik Indonesia Tahun 1945 antara lain adalah memajukan kesejahteraan umum. Untuk mencapai tujuan tersebut, perlu menggali dan mengembangkan potensi yang terdapat dalam pranata keagamaan yang memiliki manfaat ekonomis. Salah satu langkah strategis untuk meningkatkan kesejahteraan umum, perlu meningkatkan peran wakaf sebagai pranata keagamaan yang tidak hanya bertujuan menyediakan berbagai sarana ibadah dan sosial, tetapi juga memiliki kekuatan ekonomi yang berpotensi, antara lain untuk memajukan kesejahteraan umum, sehingga perlu dikembangkan pemanfaatannya sesuai dengan prinsip syariah. Praktik wakaf yang terjadi dalam kehidupan masyarakat belum sepenuhnya berjalan tertib dan efisien sehingga dalam berbagai kasus harta benda wakaf tidak terpelihara sebagaimana mestinya, terlantar atau beralih ke tangan pihak ketiga dengan cara melawan hukum. Keadaan demikian itu, tidak hanya karena kelalaian atau ketidakmampuan Nazhir dalam mengelola dan mengembangkan harta benda wakaf tetapi karena juga sikap masyarakat yang kurang peduli atau belum memahami status harta benda wakaf yang seharusnya dilindungi demi untuk kesejahteraan umum sesuai dengan tujuan, fungsi, dan peruntukan wakaf.
Jika dipahami dalam penjelasan tersebut tentunya sangatlah penting peran negara dalam menjaga supaya sistem keberlakuan wakaf dapat dijalankan sesuai dengan ketentuan yang berlaku. Namun tentunya hukum nasional tidak bisa mengesampingkan esensi ajaran agama yang telah ditetapkan melalui dalildalil yang dituangkan dalam alquran dan hadits.

Dalam Undang-Undang Nomor 41 tahun 2004 tentang Wakaf sifat pendekatan normatif dan doktrinal salah satu wujudnya adalah dalam hal pemberdayaan. Dalam Undang-Undang Nomor 41 tahun 2004 tentang Wakaf istilah pemberdayaan tidak disebut dengan istilah pemberdayaan secara tekstual, akan tetapi pemberdayaan disebut dengan sebutan pengelolaan dan pengembangan. Dalam proses dan sifat pengelolaan dan pengembangan tersebut, negara mengatur secara tegas, bahkan sifat-sifat negara memberikan unsur kekuatan berlakunya sanksi pidana diatur dalam ketentuan tersebut.

Secara teoritis hal ini menjadi bagian dari gagasan kedaulatan negara. Teori kedaulatan (negara) dalam bidang hukum ini merupakan analisis teoritis legal terhadap kekuasaan dan kedaulatan negara. Teori hukum yang berhaluan politik dalam suatu negara memang lebih banyak dikembang di zaman modern, sebab negara modern sangat memerlukan suatu landasan teoritis yang kuat dan luas. Adalah Bodin (1577), dalam bukunya Six Livres de la Republique yang pertama kali berbicara tentang teori kedaulatan ini. Menurut Bodin, kedaulatan bukan hanya kekuasaan negara yang superior dan simpel, melainkan sudah merupakan kekuasaan negara yang absolut dan berlaku terus. Memang, sekelompok manusia juga dapat memiliki kedaulatan, tetapi hal tersebut dapat menjadi suatu tirani mayoritas yang liar. Apa yang disebut dengan kedaulatan negara mencakup 
juga kedaulatan dalam membuat hukum yang berarti hukum merupakan sekumpulan perintah (command) dan negara. Sebenarnya, konsep hukum sebagai perintah bukanlah hal yang baru, di mana sudah melakukan sebuah inovasi dengan menekankan pada elemen kedaulatan (souvereignty). Meskipun begitu, banyak para ahli yang kurang sreg dengan konsepsi hukum sebagai perintah, mereka menginginkan agar konsep perintah (command), kekuasaan (power), dan paksaan (enforcement) sebaiknya ditempatkan dalam ruang lingkup ilmu politik, psikologi, dan sosiologi. Thomas Hobbes juga merupakan salah satu pelopor teori kedaulatan negara. Berbeda dengan Bodin yang melihat hukum hanya sebagai produk dan pelaksanaan kekuasaan yang aktual, sebaliknya Hobbes lebih melihat kedaulatan sebagai "hak" untuk dapat memerintah orang lain. Dasar dan hak atau otoritas tersebut adalah hukum alam yang mengharuskan manusia untuk menjalankan apa yang dijanjikannya ${ }^{4}$.

Beberapa hal yang dapat dipahami dalam peraturan perundang-undangan bisa dilihat dalam Undang-Undang wakaf Pasal 44 yaitu :

(1) Dalam mengelola dan mengembangkan harta benda wakaf, Nazhir dilarang melakukan perubahan peruntukan harta benda wakaf kecuali atas dasar izin tertulis dari Badan Wakaf Indonesia.

(2) Izin sebagaimana dimaksud pada ayat (1) hanya dapat diberikan apabila harta benda wakaf ternyata tidak dapat dipergunakansesuaidenganperuntukan yang dinyatakan dalam ikrar wakaf.

Fungsi negara dalam memberikan batasan batasan normtif tersebut dibarengi sanksi pidana apabila terjadi pelanggaraan terhadap ketentuan dalam UndangUndang wakaf tersebut yang diantaranya diatur dalam pasal 67 sebagai berikut :

${ }^{4}$ Munir Fuady, Dinamika Teori Hukum, Ghalia Indonesia, Bogor 2010, hlm. 10

66 IUS Kajian Hukum dan Keadilan
(1) Setiap orang yang dengan sengaja menjaminkan, menghibahkan, menjual, mewariskan, mengalihkan dalam bentuk pengalihan hak lainnya harta benda wakaf yang telah diwakafkan sebagaimana dimaksud dalam Pasal 40 atau tanpa izin menukar harta benda wakaf yang telah diwakafkan sebagaimana dimaksud dalam Pasal 41, dipidana dengan pidana penjara paling lama 5 (lima) tahun dan/ atau pidana denda paling banyak $\mathrm{Rp}$ 500.000.000,00 (lima ratus juta rupiah).

(2) Setiap orang yang dengan sengaja mengubah peruntukan harta benda wakaf tanpa izin sebagaimana dimaksud dalam Pasal 44, dipidana dengan pidana penjara paling lama 4 (empat) tahun dan/atau pidana denda paling banyak Rp 400.000.000,00 (empat ratus juta rupiah).

(3) Setiap orang yang dengan sengaja menggunakan atau mengambil fasilitas atas hasil pengelolaan dan pengembangan harta benda wakaf melebihi jumlah yang ditentukan sebagaimana dimaksud dalam Pasal 12 , dipidana dengan pidana penjara paling lama 3 (tiga) tahun dan/atau pidana denda paling banyak Rp 300.000.000,00 (tiga ratus juta rupiah).

Selain sanksi pidana yang ditegaskan dalam pasal 67 di atas, terdapat pula sanksi administrasi yang ditegaskan dalam pasal 68 sebagai berikut :

(1)Menteri dapat mengenakan sanksi administratif atas pelanggaran tidak didaftarkannya harta benda wakaf oleh lembaga keuangan syariah dan PPAIW sebagaimana dimaksud dalam Pasal 30 dan Pasal 32.

(2)Sanksi administratif sebagaimana dimaksud pada ayat (1) berupa:

a. peringatan tertulis;

b. penghentian sementara atau pencabutan izin kegiatan di bidang wakafbagilembagakeuangansyariah; 
c. penghentian sementara dari jabatan ataupenghentiandarijabatanPPAIW.

(3)Ketentuan lebih lanjut mengenai pelaksanaan sanksi administratif sebagaimana dimaksud pada ayat (1) dan ayat (2) diatur dengan Peraturan Pemerintah

Meskipun sanksi pidana tersebut diberlakukan, artinya intervensi negara bukan diposisikan sebagai upaya mengintervensi ajaran agama. Posisi negara hanya menjaga ketertiban dan berjalannya negara agar sesuai dengan koridor yang berlaku. Beberapa gagasan pasal telah menunjukkan bahwa berjalannya ketentuan wakaf harus sesuai dengan ajaran agama diantaranya dalam pasal 43 yaitu :

(1)Pengelolaan dan pengembangan harta benda wakaf oleh Nazhir sebagaimana dimaksud dalam Pasal 42 dilaksanakan sesuai dengan prinsip syariah.

(2)Pengelolaan dan pengembangan harta benda wakaf sebagaimana dimaksud pada ayat(1) dilakukan secara produktif.

(3)Dalam hal pengelolaan dan pengembangan harta benda wakaf yang dimaksud pada ayat (1) diperlukan penjamin, maka digunakan lembaga penjamin syariah.

Pada praktisnya hal ini secara tidak langsung akan mendukung proses pengelolaan wakaf sehingga dapat berdayaguna dan berhasilguna. Disamping itu reorientasi dari wakaf adalah sebagai upaya mewujudkan lembaga wakaf sebagai pranata keagamaan yang memiliki potensi dan manfaat ekonomi perlu dikelola secara efektif dan efisien untuk kepentingan ibadah dan untuk memajukan kesejahteraan umum. Hal ini sebagaimana termaktub dalam bagian pertimbangan Undang-Undang Wakaf.

Pada sisi lain, dalam bagian penjelasan terdapat formulasi pengaturan wakaf yang dituangkan dalam undang-undang yang seyogyanya ditafsirkan sebagai doktrin orientasi negara dalam mendorong peran strategis wakaf tersebut. Beberapa hal yang dapat ditegaskan dalam penjelasan undang-undang tersebut sebagai berikut :

1. Untuk menciptakan tertib hukum dan administrasi wakaf guna melindungi harta benda wakaf, undang-undang ini menegaskan bahwa perbuatan hukum wakaf wajib dicatat dan dituangkan dalam akta ikrar wakaf dan didaftarkan serta diumumkan yang pelaksanaannya dilakukan sesuai dengan tata cara yang diatur dalam peraturan perundangundangan yang mengatur mengenai wakaf dan harus dilaksanakan. Undangundang ini tidak memisahkan antara wakaf ahli yang pengelolaan dan pemanfaatan hartabenda wakaf terbatas untuk kaum kerabat (ahli waris) dengan wakaf khairi yang dimaksudkan untuk kepentingan masyarakat umum sesuai dengan tujuan dan fungsi wakaf.

2. Ruang lingkup wakaf yang selama ini dipahami secara umum cenderung terbataspadawakafbendatidakbergerak seperti tanah dan bangunan, menurut undang-undang ini Wakif dapat pula mewakafkan sebagian kekayaannya berupa harta benda bergerak, baik berwujud atau tidak berwujud yaitu uang, logam mulia, surat berharga, kendaraan, hak kekayaan intelektual, hak sewa, dan benda bergerak lainnya. Dalam hal benda bergerak berupa uang, Wakif dapat mewakafkan melalui Lembaga Keuangan Syariah. Yang dimaksud dengan Lembaga Keuangan Syariah adalah badan hukum Indonesia yang dibentuk sesuai dengan peraturan perundang-undangan yang berlaku yang bergerak di bidang keuangan syariah, misalnya badan hukum di bidang perbankan syariah ${ }^{5}$. Dimungkinkannya wakaf benda bergerak berupa uang

\footnotetext{
${ }^{5}$ Bank syariah adalah bank yang menghimpun dana (termasuk dana wakaf ummat) sesuai dengan hukum Islam (prinsip syariah) yang bebas dari transaksi ribawi. Lihat Fatahullah, S. H. "Plurality Of Shariah Banking Dispute Settlement Method In Indonesia." Jurnal IUS Kajian Hukum dan Keadilan 2.3 (2014). hlm. 539
} 
melalui Lembaga Keuangan Syariah dimaksudkan agar memudahkan Wakif untuk mewakafkan uang miliknya.

3. Peruntukan harta benda wakaf tidak semata-mata untuk kepentingan sarana ibadah dan sosial tetapi juga diarahkan untuk memajukan kesejahteraan umum dengan cara mewujudkan potensi dan manfaat ekonomi harta benda wakaf. Hal itu memungkinkan pengelolaan harta benda wakaf dapat memasuki wilayah kegiatan ekonomi dalam arti luas sepanjang pengelolaan tersebut sesuai dengan prinsip manajemen dan ekonomi syariah.

4. Untukmengamankan hartabendawakaf dari campur tangan pihak ketiga yang merugikan kepentingan wakaf, perlu meningkatkan kemampuan profesional Nazhir.

5. Undang-undang ini juga mengatur pembentukan Badan Wakaf Indonesia yang dapat mempunyai perwakilan di daerah sesuai dengan kebutuhan. Badan tersebut merupakan lembaga independen yang melaksanakan tugas di bidang perwakafan yang melakukan pembinaan terhadap Nazhir, melakukan pengelolaan dan pengembangan harta benda wakaf berskala nasional dan internasional, memberikan persetujuan atas perubahan peruntukan dan status harta benda wakaf, dan memberikan saran dan pertimbangan kepada pemerintah dalam penyusunan kebijakan di bidang perwakafan.

Beberapa pasal dan penjelasannya juga menegaskan adanya bentuk dan sistem pengelolaan wakaf secara produktif yang salah satunya dijabarkan dalam Pasal 43 Ayat (2), bahwa pengelolaan dan pengembangan harta benda wakaf dilakukan secara produktif antara lain dengan cara pengumpulan, investasi, penanaman modal, produksi, kemitraan, perdagangan, agrobisnis, pertambangan, perindustrian, pengembangan teknologi, pembangunan gedung, apartemen, rumah susun, pasar swalayan, pertokoan, perkantoran, sarana pendidikan ataupun sarana kesehatan, dan usaha-usaha yang tidak bertentangan dengan syariah. Yang dimaksud dengan lembaga penjamin syariah adalah badan hukum yang menyelenggarakan kegiatan penjaminan atas suatu kegiatan usaha yang dapat dilakukan antara lain melalui skim asuransi syariah atau skim lainnya sesuai dengan ketentuan peraturan perundangundangan yang berlaku.

Model dan gagasan pengembangan dan pengelolaan yang menjadi bentuk lain dari istilah pemberdayaan wakaf tersebut tentunya mengalami kendala secara subtantif apabila tidak dibarengi dengan konsep keberpihakan kultural. Gagasan kultural adalah upaya mensinergikan dan membangun format ideal suatau bentuk pemberdayaan wakaf melalui pengelolaan dan pemanfaatan dengan mendorong masyarakat untuk berpartisipasi secara aktif. Gagasan ini tentunya akan menjadi bentuk budaya hukum yang jelas dan berorientasi.

Untuk memahami maksud budaya hukum terlebih dulu perlu digambarkan secara umum tentang pengertian kebudayaan. Sebab budaya hukum merupakan bagian dan kebudayaan pada umumnya. Kebudayaan telah redefinisikan dengan berbagai pendekatan oleh berbagai pakar. Di dalam buku Communicating Between Cultures disebutkan bahwa Taylor, pada tahun 1871, mendefinisikan kebudayaan sebagai "keseluruhan kompleks yang memuat pengetahuan kepercayaan, seni, moral, hukum, adat kebiasaan, dan segala kemampuan serta kebiasaan yang diperoleh manusia sebagai anggota masyarakat. Sementara itu, Clyde Kluckhohn mengartikan kebudayaan sebagai keseluruhan hidup suatu masyarakat sebagai warisan sosial yang diperoleh para individu dan kelompoknya. Dalam pengertian yang lebih fungsional, 
kebudayaan merupakan desain untuk hidup dalam arti suatu perencanaan dan sesuai dengan perencanaan itu, masyarakat kemudian mengadaptasikan dirinya pada lingkungan fisik, sosial, dan ide. Dari banyak pengertian itu, dapat dikemukakan beberapa dimensi tentang kebudayaan. Pertama, kebudayaan terkait dengan ciri manusia sendiri sebagai makhluk yang "belum selesai" dan harus berkembang sehingga kebudayaan terkait pula dengan usaha pemenuhan kebutuhan manusia yang asasi; Kedua, kebudayaan dapat dipahami juga sebagai suatu strategi manusia dalam menghadapi lingkungannya; Ketiga, kebudayaan merupakan suatu sistem sosial yang tidak mandiri atau terlepas dan sistem sosial ekonomis. Pada satu sisi kebudayaan itu mengondisikan sistem sosial dalam arti ikut membentuk atau mengarahkan, tetapi juga dikondisikan oleh sistem sosial ekonomi dalam arti dipengaruhi olehnya; Keempat, kebudayaan merupakan satu sistem makna sehingga pendekatannya pun harus menggunakan metode interpretasi ${ }^{6}$.

Nuansa dari pendekatan kebudayaan tersebut lebih akan bersinergi dengan aspek norma dan nilai yang terdapat dalam gagasan perundang-undangan dan tidak pula mengesampingkan unsur-unsur syar'iyah yang menjadi literatur timbulnya wakaf. Hal inilah yang perlu direposisi dalam menekankan upaya pemberdayaan wakaf.

Budaya hukum dapat pula diartikan sikap masyarakat terhadap hukum dan sistem hukum seperti kepercayaan, nilai, ide, dan harapan-harapan. Budaya hukum juga sering diartikan sebagai situasi pemikiran sosial dan kekuatan sosial yang menentukan bagaimana hukum itu dituruti, dilanggar, dan disimpangi. Dan pengertian ini menjadi jelas bahwa tanpa

${ }^{6}$ Moh. Mahfud MD, Perdebatan Hukum Tata Negara Pasca Amandemen Konstitusi, Raja Grafindo Persada, Jakarta, 2013, hlm. 207 budaya hukum, suatu sistem hukum tidak akan berdaya. Dapat juga dikemukakan bahwa budaya hukum itu merupakan bagian dan sistem hukum yang juga memiliki dua bagian lain, yakni struktur hukum dan substansi hukum. Struktur, substansi, dan budaya hukum merupakan subsistem dan sistem hukum yang saling berkaitan sehingga jika budaya hukum tidak ada maka sistem hukum itu menjadi lumpuh. Ketiga subsistem itu dapat digambarkan dalam hubungan antara mesin, cara menggerakkan mesin, dan penggerak mesin. Struktur hukum dapat diumpamakan sebagai mesin, substansi hukum adalah bagaimana mesin itu bergerak, dan budaya hukum adalah apa dan siapa saja yang memutuskan untuk menjalankan mesin dan siapa yang menghidupkan atau mematikan serta menentukan bagaimana mesin itu akan digunakan ${ }^{7}$.

Unsur-unsur yang berlaku dalam budaya hukum disini adalah sekiranya dapat mengaktifkan nilai-nilai legalitas subtansi pengelolaan dan pemanfaat wakaf sesuai dengan peruntukannya. Efektifitas budaya hukum disini bukan hanya ditekankan pada suatu kewenangan subjektif dari masyarakat, akan tetapi juga budaya hukum struktural atau kelembagaan harus pula ditingkatkan.

Dalam ketentuan Undang-Undang Nomor 41 tahun 2004 tentang Wakaf beberapa kelembagaan telah dibentuk dalam mendorong pemberdayaan wakaf diantaranya adalah Badan Wakaf Indonesia atau yang dikenal dengan sebutan BWI, Pejabat Pembuat Akta Ikrar Wakaf yang selanjutnya disingkat PPAIW merupakan pejabat berwenang yang ditetapkan oleh Menteri untuk membuat akta ikrar wakaf termasuk juga Nadzir yang harus tersertifikasi.

Unsur pelaksana pengelolaan dan pemanfaatan wakaf tersebut tentunya harus bersinergi dengan orientasi

\footnotetext{
${ }^{7}$ Ibid. hlm. 208-209
} 
pemberdayaan wakaf yang dalam ketentuan peraturan yang berlaku struktural tersebut menjadi penentu tercapainya tujuan pemberdayaan. Baik PPAIW, BWI, Nadzir harus menjalankan dogma-dogma tersebut secara berorientasi pada peningkatan pemberdayaan wakaf.

Esensi dari budaya hukum yang harus direposisi dalam pemberdayaan wakaf adalah semata-mata menempatkan hukum yang memiliki makna sosial. Hukum memiliki makna sosial di samping makna yuridis-normatif yang melekat. Makna sosial dan hukum dapat memberikan gambaran kepada kita bagaimana konsep yuridis normatif dijalankan di masyarakat. Berbagai doktrin yang lazim diterima sebagai sesuatu "yang baik-baik" begitu juga dapat mempunyai makna sosial yang tidak persis sama seperti dipikirkan orang. Dalam doktrin ROL misalnya, diterima asas "Supremacy of Law" dan kita menerima begitu saja asas tersebut sebagai sesuatu yang memang baik, adil dan sebagainya. Tetapi makna sosial dan asas seperti itu dapat menjadi lain apabila diterapkan dalam kenyataan. Dalam konteks kenyataan kita akan menghadapi para justisiabel yang berbeda dalam kemampuan ekonominya, dan karena itu tidak semua orang dapat menikmati bekerjanya asas yang tampak netral atau non diskriminatif tersebut dengan sama baiknya. Pengamatan sosiologis menunjukkan, bahwa dalam dunia hukum tidak hanya terjadi pergumulan yuridis, tetapi juga ekonomi dengan segala akibat dan hasilnya. Marc Galanter misalnya sampai pada suatu kesimpulan bahwa dengan kekuatan ekonomi (uang), maka seseorang dapat memenangkan suatu perkara ("the haves come out ahead"). Dengan demikian dapat dikatakan bahwa, doktrin "supremacy of law" dapat mempunyai makna sosial yang lain, yang bahkan dapat menimbulkan ketidakadilan atau efek diskriminatif.
Kebenaran pernyataan-pernyataan tersebut di muka, dapat terbukti dan praktik-praktik hukum di Indonesia. Indonesia ialah negara berdasarkan hukum. Konsepsi negara berdasar atas hukum Indonesia memiliki ciri-ciri (yang dioper dan Rule of Law):

1. Adanyaasaslegalitasyuridis(jugaberarti supremacy of law)

2. Adanya peradilan yang bebas, merdeka, mandiri (independen judiciary) dan

3. Adanya pengakuan dan perlindungan terhadap hak asasi manusia (equality before the law). ${ }^{8}$

\section{SIMPULAN}

Terbentuknya Undang-Undang Nomor 41 tahun 2004 tentang Wakaf menjadi cikal bakal konsep pemberdayaan yang tepat bagi wakaf untuk terus dikembangkan. Esensi Undang-Undang Nomor 41 tahun 2004 tentang Wakaf bukan hanya ditafsirkan sebuah peran negara dalam mewujudkan ketertiban, akan tetapi juga menjadi bagian mendukung tujuan negara yaitu mensejahterakan masyarakat. Namun tentunya tujuan-tujuan tersebut tidak mengesampingkan esensinya wakaf yaitu berpedoman pada syariah. Namun tentunya, Undang-Undang Nomor 41 tahun 2004 tentang Wakaf terdapat adanya sanksi pidana yang diberlakukan, artinya intervensi negara bukan untuk diposisikan sebagai upaya mengintervensi ajaran agama. Posisi negara hanya menjaga ketertiban dan berjalannya negara agar sesuai dengan koridor yang berlaku.

Kebutuhan optimalisasi pemberdayaan wakaf melalui Undang-Undang Nomor 41 tahun 2004 tentang Wakaf tidaklah sebuah wujud wawasan yang strategis untuk diterapakan apabila budaya hukum baik masyarakat maupun struktural kelembagaan wakaf tidak berjalan dengan baik. Unsur yang berlaku dalam budaya hukum disini adalah sekiranya dapat

${ }^{8}$ Suteki, Desain Hukum Di Ruang Sosial, Thafa Media, Yogyakarta, 2013, hlm. 182-183 
Muh. Junaidi, Abdullah Kelib \& Diah Sulistiyani R S|Reposisi Peran Waqaf Dalam Pemberdayaan........

mengaktifkan nilai-nilai legalitas subtansi pengelolaan dan pemanfaat wakaf sesuai dengan peruntukannya. Esensi dari budaya hukum yang harus direposisi dalam pemberdayaan wakaf adalah semata-mata menempatkan hukum yang memiliki makna sosial. Hukum memiliki makna sosial di samping makna yuridis-normatif yang melekat. Makna sosial dan hukum dapat memberikan gambaran kepada kita bagaimana konsep yuridis normatif dijalankan di dalam masyarakat. Melalui gagasan tersebut maka wakaf tidak hanya sekedar apa yang diberikan dari Waqif, diterima oleh Nadzir dan kemudian diserahkan sesuai peruntukannya, namun harus pula memposisikan esensi pertimbangan pemberdayaan secara utuh.

\section{DAFTAR PUSTAKA}

\section{Buku-Buku}

Ahmad Kamil, M. Fauzan, 2004, KaidahKaidah Hukum Yurisprudensi, Prenada Media, Jakarta.)

Moh. Mahfud MD, 2013, Perdebatan Hukum Tata Negara Pasca Amandemen Konstitusi, Raja Grafindo Persada, Jakarta.

Muhammad Tahir Azhary, 2003, Negara Hukum, Prenada Media,Jakarta.)

Munir Fuady, 2010, Dinamika Teori Hukum, Ghalia Indonesia, Bogor.

Suteki, 2013, Desain Hukum Di Ruang Sosial,Thafa Media, Yogyakarta.

\section{Jurnal \& Internet}

Fatahullah, S. H. "Plurality Of Shariah Banking Dispute Settlement Method In Indonesia." Jurnal IUS Kajian Hukum dan Keadilan 2.3 (2014)

Database dan Potensi Wakaf, diunduh pada situs http://www.bwi.or.id pada 25 Agustus 2017

\section{Peraturan perundang-undangan}

Undang-Undang Dasar Negara Republik Indonesia tahun 1945

Undang-Undang Nomor 41 tahun 2004 tentang Wakaf

Peraturan Pemerintah Nomor 42 Tahun 2006 tentang Pelaksanaan Undang-Undang Nomor 41 Tahun 2004 tentang Wakaf.

Peraturan Menteri Agama Nomor 73 Tahun 2013 tentang Tata Cara Perwakafan Benda Tidak Bergerak dan Benda Bergerak Selain Uang.

Peraturan Menteri Agama Nomor 4 Tahun 2009 tentang Administrasi Pendaftaran Wakaf Uang

Peraturan Badan Wakaf Indonesia Nomor 1 Tahun 2008 tentang Prosedur Penyusunan Rekomendasi terhadapPermohonan Penukaran/ Perubahan Status Harta Benda Wakaf

Peraturan Badan Wakaf Indonesia Nomor 3 Tahun 2008 tentang Tata Cara Pendaftaran dan Penggantian Nazhir Harta Benda Wakaf Tidak Bergerak Berupa Tanah.

Peraturan Badan Wakaf Indonesia Nomor

1 Tahun 2009 tentang Pedoman Pengelolaan dan Pengembangan Harta Benda Wakaf Berupa Uang. 